\title{
Segetibacter koreensis gen. nov., sp. nov., a novel member of the phylum Bacteroidetes, isolated from the soil of a ginseng field in South Korea
}

\author{
Correspondence \\ Wan-Taek Im \\ wandra@kaist.ac.kr \\ Sung-Taik Lee \\ e_stlee@kaist.ac.kr
}

\author{
Dong-Shan An, Hyung-Gwan Lee, Wan-Taek Im, Qing-Mei Liu \\ and Sung-Taik Lee
}

\author{
Department of Biological Sciences, Korea Advanced Institute of Science and Technology, \\ 373-1 Guseong-dong, Yuseong-gu, Daejeon 305-701, Republic of Korea
}

Bacteria constituting the Cytophaga-FlavobacteriumBacteroides group, also referred to as the phylum Bacteroidetes (Garrity \& Holt, 2001), are widely distributed over a diverse range of ecological niches. Although they are dominant in marine environments (Bowman et al., 1997), they are also found in soil, fresh water, plants and in the air (Buczolits et al., 2002). During the course of a study on the culturable bacterial community of soil from a ginseng field in South Korea, a large number of novel bacterial strains were isolated (Im et al., 2005). One of these isolates, Gsoil $664^{\mathrm{T}}$, was found to be a member of the phylum Bacteroidetes and was subjected to further taxonomic investigation. On the basis of the results obtained in this study, we propose that strain Gsoil $664^{\mathrm{T}}$ represents a new genus and novel species.

Strain Gsoil $664^{\mathrm{T}}$ was isolated from soil from a ginseng field in Pocheon Province, South Korea. The soil sample was thoroughly suspended with $50 \mathrm{mM}$ phosphate buffer $(\mathrm{pH} 7.0)$ and the suspension was then spread on one-fifthstrength modified R2A agar plates (containing, $\mathrm{l}^{-1}, 0.25 \mathrm{~g}$ tryptone, $0.25 \mathrm{~g}$ peptone, $0.25 \mathrm{~g}$ yeast extract, $0.125 \mathrm{~g}$ malt

The GenBank/EMBL/DDBJ accession number for the 16S rRNA gene sequence of strain Gsoil $664^{\top}$ is $A B 267478$. extract, $0.125 \mathrm{~g}$ beef extract, $0.25 \mathrm{~g}$ Casamino acids, $0.25 \mathrm{~g}$ soytone, $0.5 \mathrm{~g}$ glucose, $0.3 \mathrm{~g}$ soluble starch, $0.2 \mathrm{~g}$ xylan, $0.3 \mathrm{~g}$ sodium pyruvate, $0.3 \mathrm{~g} \mathrm{~K}_{2} \mathrm{HPO}_{4}, 0.05 \mathrm{~g} \mathrm{MgSO}_{4}$, $0.05 \mathrm{~g} \mathrm{CaCl}_{2}$ and $15 \mathrm{~g}$ agar) after serial dilution with $50 \mathrm{mM}$ phosphate buffer ( $\mathrm{pH} \mathrm{7.0)}$. The plates were incubated at $30{ }^{\circ} \mathrm{C}$ for 1 month. Single colonies on the plates were purified by transferring them onto new plates for further incubation on full-strength modified R2A or one-half-strength modified R2A. The purified colonies were tentatively identified using partial sequences of the $16 \mathrm{~S}$ rRNA gene (Im et al., 2005). As strain Gsoil $664^{\mathrm{T}}$ could grow well both on full-strength modified R2A agar and on commercial R2A agar (Difco), it was routinely cultured on R2A agar or one-half-strength R2A agar (Difco) at $30{ }^{\circ} \mathrm{C}$ and maintained as a glycerol suspension $(20 \%$, w/v) at $-70{ }^{\circ} \mathrm{C}$.

The Gram-stain reaction was performed using the nonstaining method, as described by Buck (1982). Cell morphology was observed at $\times 1000$ magnification with a light microscope (Nikon), using cells grown for 3 days at $30{ }^{\circ} \mathrm{C}$ on R2A agar. Catalase activity was determined by assessing bubble production in $3 \%(\mathrm{v} / \mathrm{v}) \mathrm{H}_{2} \mathrm{O}_{2}$ and oxidase activity was determined using $1 \%(\mathrm{w} / \mathrm{v})$ tetramethyl-p-phenylenediamine. Carbon-source utilization and enzyme activities 
were tested by using the API 20NE, API ID 32GN and API ZYM test kits (bioMérieux). The ability to use nitrate as an alternative terminal electron acceptor was tested in serum bottles by adding sodium thioglycolate $\left(1 \mathrm{~g} \mathrm{l}^{-1}\right)$ to R2A broth and substituting the upper airspace with nitrogen gas. The anaerobic nitrate-reduction test for determining the final electron acceptor was performed in serum bottles by adding sodium thioglycolate $\left(1 \mathrm{~g} \mathrm{l}^{-1}\right)$ and $10 \mathrm{mM}$ $\mathrm{KNO}_{3}$ to $\mathrm{R} 2 \mathrm{~A}$ broth, under nitrogen gas. Tests for the degradation of DNA [performed by flooding DNase agar (Scharlau) plates with $1 \mathrm{M} \mathrm{HCl}$, casein, chitin, starch (Atlas, 1993), xylan and cellulose (Ten et al., 2004) were performed and evaluated after 10 days. Growth at various temperatures $\left(4,15,20,25,30,37\right.$ and $\left.42{ }^{\circ} \mathrm{C}\right)$ and $\mathrm{pH}$ values ( $\mathrm{pH} 5.0-10.0$, in increments of $0.5 \mathrm{pH}$ units) was assessed after 5 days incubation. Salt tolerance was tested on R2A agar supplemented with $1-10 \%(w / v) ~ N a C l$ after 5 days incubation. Growth on nutrient agar, trypticase soy agar (TSA) and MacConkey agar was also evaluated at $30{ }^{\circ} \mathrm{C}$.

Strain Gsoil $664^{\mathrm{T}}$ was strictly aerobic, Gram-negative, heterotrophic and comprised non-motile, non-sporeforming, rod-shaped cells. The strain did not grow on nutrient agar, MacConkey agar or TSA, whereas it grew weakly on one-tenth-strength TSA. The ability to reduce nitrate was absent. Other physiological characteristics of Gsoil $664^{\mathrm{T}}$ are summarized in the species description and comparisons of selective characteristics with those of closely related type strains are shown in Table 1.

For measurement of the $\mathrm{G}+\mathrm{C}$ content of the chromosomal DNA, genomic DNA of the novel strain was extracted and purified, as described by Moore \& Dowhan (1995), and enzymically degraded into nucleosides. The $\mathrm{G}+\mathrm{C}$ content was then determined as described by Mesbah et al. (1989), using reversed-phase HPLC. Isoprenoid quinones were extracted with chloroform/methanol $(2: 1, \mathrm{v} / \mathrm{v})$, evaporated under vacuum conditions and then re-extracted in $n$ hexane/water $(1: 1, \mathrm{v} / \mathrm{v})$. The crude $\mathrm{n}$-hexane-quinone solution was purified using Sep-Pak Vac silica cartridges (Waters) and was subsequently analysed by HPLC as described previously (Hiraishi et al., 1996). The cellular fatty acid profile was determined from biomass harvested from one-tenth-strength TSA (Difco) after 3 days incubation. The cellular fatty acids were saponified, methylated and extracted according to the protocol of the Sherlock Microbial Identification System (MIDI). Fatty acids were analysed with a GC (model 6890; Hewlett Packard) and identified by using the Microbial Identification software package (Sasser, 1990).

The $\mathrm{G}+\mathrm{C}$ content of the genomic DNA of strain Gsoil $664^{\mathrm{T}}$ was $40.4 \mathrm{~mol} \%$, a value that is lower than those of the most phylogenetically related genera $(47.2-48.9 \mathrm{~mol} \%$ for the genus Terrimonas and $44.3-45.8 \mathrm{~mol} \%$ for the genus Niastella). The major respiratory quinone was MK-7. As shown in Table 2, the major fatty acids of this strain were iso- $\mathrm{C}_{15: 0}(23.4 \%)$, iso- $\mathrm{C}_{17: 0} 3-\mathrm{OH}(14.5 \%)$, iso- $\mathrm{C}_{15: 1}$
(14.4\%) and $\mathrm{C}_{16: 1} \omega 5 c(12.5 \%)$. The presence of iso- $\mathrm{C}_{13: 0}$ $3-\mathrm{OH}, \mathrm{C}_{18: 0}$ and summed feature 4 , and the absence of iso- $\mathrm{C}_{15: 0} 3-\mathrm{OH}, \mathrm{C}_{16: 0} 3-\mathrm{OH}$, and an unknown fatty acid with an equivalent chain-length of 16.582, together with some quantitative differences in the fatty acid composition, served to distinguish strain Gsoil $664^{\mathrm{T}}$ from other recognized species in phylogenetically related genera (Table 2).

Extraction of genomic DNA was performed with a commercial genomic DNA extraction kit (Solgent) and PCR-mediated amplification of the 16S rRNA gene and sequencing of the purified PCR product were carried out according to Kim et al. (2005). Full sequences of the $16 \mathrm{~S}$ rRNA gene were compiled using SeqMan software (DNASTAR). The 16S rRNA gene sequences of related taxa were obtained from GenBank. Multiple alignments were performed with the CLUSTAL_X program (Thompson et al., 1997), gaps were edited in the BioEdit program (Hall, 1999) and evolutionary distances were calculated using the Kimura two-parameter model (Kimura, 1983). Phylogenetic trees were constructed using a neighbour-joining method (Saitou \& Nei, 1987) with the MEGA3 program (Kumar et al., 2004); bootstrap percentages were based on 1000 replications (Felsenstein, 1985).

An almost-complete 16S rRNA gene sequence (1479 bp) for strain Gsoil $664^{\mathrm{T}}$ was determined and subjected to comparative analysis. A phylogenetic analysis based on $16 \mathrm{~S}$ rRNA gene sequences indicated that the isolate formed a cluster with several uncultured bacterial clones and with the established genera Terrimonas, Niastella and Chitinophaga (phylum Bacteroidetes). However, it was difficult to allocate the isolate to any of these previously established genera (Fig. 1). The levels of $16 \mathrm{~S}$ rRNA gene sequence similarity between strain Gsoil $664^{\mathrm{T}}$ and the type strains of recognized species of these genera ranged from 86.7 to $90.7 \%$. The unique phylogenetic position of the novel isolate, shown in Fig. 1, and the low levels of gene sequence similarity with respect to any other recognized related bacterial species demonstrate that strain Gsoil $664^{\mathrm{T}}$ represents a novel genus.

On the basis of the data and observations described above, it is appropriate to conclude that strain Gsoil $664^{\mathrm{T}}$ represents a new genus and novel species of the phylum Bacteroidetes, for which the name Segetibacter koreensis gen. nov., sp. nov. is proposed.

\section{Description of Segetibacter gen. nov.}

Segetibacter (Se.ge'ti.bac'ter. L. n. seges -etis soil; N.L. n. bacter a rod; N.L. masc. n. Segetibacter rod from soil).

Gram-negative, oxidase-positive and catalase-positive. Strictly aerobic and chemoheterotrophic. Nitrate is not reduced to nitrite. The major fatty acids are iso- $\mathrm{C}_{15: 0}$, iso$\mathrm{C}_{17: 0} 3-\mathrm{OH}$, iso- $\mathrm{C}_{15: 1}$ and $\mathrm{C}_{16: 1} \omega 5 c$. MK-7 is the predominant respiratory quinone. Positioned phylogenetically in the phylum Bacteroidetes. The type species is Segetibacter koreensis. 
Table 1. Biochemical characteristics of strain Gsoil $664^{\top}$ and related taxa

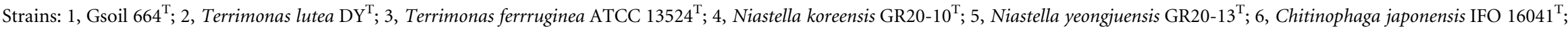

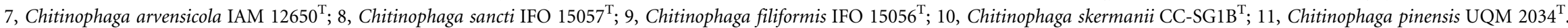

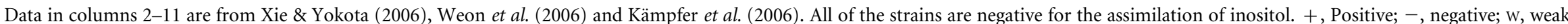
reaction; $v$, variable among studies; ND, no data available.

\begin{tabular}{|c|c|c|c|c|c|c|c|c|c|c|c|}
\hline Characteristic & 1 & 2 & 3 & 4 & 5 & 6 & 7 & 8 & 9 & 10 & 11 \\
\hline Pigment & Yellow & Red or yellow & $\begin{array}{l}\text { Yellowish } \\
\text { orange }\end{array}$ & Light yellow & Milky & $\begin{array}{c}\text { Yellowish } \\
\text { orange }\end{array}$ & $\begin{array}{c}\text { Yellowish } \\
\text { orange }\end{array}$ & $\begin{array}{l}\text { Golden } \\
\text { yellow }\end{array}$ & $\begin{array}{l}\text { Golden } \\
\text { yellow }\end{array}$ & Yellow & Yellow \\
\hline Cell length $(\mu \mathrm{m})$ & $1-2$ & $1-2$ & $0.6-4$ & $10-50$ & $10-40$ & $2-18$ & $0.6-4$ & $2-15$ & $30-80$ & $1-2$ & $<40$ \\
\hline Gliding movement & - & - & - & + & + & + & - & + & + & - & + \\
\hline Major fatty acids $(>20 \%)$ & iso- $\mathrm{C}_{15: 0}$ & $\begin{array}{l}\text { iso- } C_{15: 0} \\
\text { iso- } C_{15: 1}\end{array}$ & $\begin{array}{l}\text { iso- } C_{15: 0} \\
\text { iso- } C_{15: 1}\end{array}$ & $\begin{array}{c}\text { iso- } \mathrm{C}_{15: 0} \\
\text { iso- } \mathrm{C}_{17: 0} \\
3-\mathrm{OH}\end{array}$ & $\begin{array}{c}\text { iso- } \mathrm{C}_{15: 0} \\
\text { iso- } \mathrm{C}_{17: 0} \\
3-\mathrm{OH}\end{array}$ & $\begin{array}{l}\text { iso- } \mathrm{C}_{15: 0} \\
\mathrm{C}_{16: 1} \omega 5 c\end{array}$ & $\begin{array}{l}\text { iso- } \mathrm{C}_{15: 0} \\
\mathrm{C}_{16: 1} \omega 5 c\end{array}$ & iso- $\mathrm{C}_{15: 0}$ & $\begin{array}{l}\text { iso- } \mathrm{C}_{15: 0} \\
\mathrm{C}_{16: 1} \omega 5 c\end{array}$ & $\begin{array}{l}\text { iso- } \mathrm{C}_{15: 0} \\
\mathrm{C}_{16: 1} \omega 5 c\end{array}$ & $\begin{array}{l}\text { iso- } \mathrm{C}_{15: 0} \\
\mathrm{C}_{16: 1} \omega 5 c\end{array}$ \\
\hline Oxidase & + & + & + & - & + & + & + & ND & + & + & + \\
\hline Catalase & + & $\mathrm{W}$ & + & - & - & + & + & - & + & + & - \\
\hline \multicolumn{12}{|l|}{ Hydrolysis of: } \\
\hline Casein & - & $\mathrm{ND}$ & - & + & + & - & ND & ND & - & ND & + \\
\hline Chitin & - & - & - & + & + & - & $\mathrm{ND}$ & - & - & $\mathrm{ND}$ & + \\
\hline DNA & - & ND & - & - & - & + & + & ND & + & ND & - \\
\hline Gelatin & - & + & - & + & + & + & $\mathrm{v}$ & + & $\mathrm{w}$ & + & + \\
\hline Starch & - & ND & + & - & - & - & $\mathrm{v}$ & + & - & ND & - \\
\hline Urea & + & - & - & - & - & $\mathrm{ND}$ & - & ND & ND & - & + \\
\hline Growth at $37^{\circ} \mathrm{C}$ & - & + & + & + & - & + & - & - & + & + & + \\
\hline $\begin{array}{l}\text { Highest } \mathrm{NaCl} \text { conc. }(\%, w / v) \text { tolerated } \\
\text { Assimilation of: }\end{array}$ & 3.0 & 1.0 & 1.0 & ND & ND & 2.0 & 2.0 & 1.0 & 0.3 & ND & $\mathrm{ND}$ \\
\hline $\mathrm{N}$-Acetyl-D-glucosamine & + & + & - & - & - & + & + & - & - & + & + \\
\hline L-Arabinose & - & + & - & - & - & + & + & + & - & - & + \\
\hline Gluconate & - & - & - & - & - & - & - & + & - & - & - \\
\hline D-Mannose & + & + & + & - & - & + & + & + & + & + & + \\
\hline Maltose & + & + & + & - & - & + & + & + & + & + & + \\
\hline$\alpha$-D-Melibiose & $\mathrm{W}$ & + & - & - & - & + & + & + & + & + & - \\
\hline L-Rhamnose & + & - & + & - & - & + & + & - & - & - & + \\
\hline D-Ribose & - & - & - & - & - & - & + & - & - & - & - \\
\hline Sucrose & - & + & - & - & - & + & + & - & + & - & + \\
\hline Salicin & + & - & - & - & - & + & + & - & + & + & + \\
\hline Nitrate reduction & - & - & - & - & - & + & $\mathrm{V}$ & + & + & ND & - \\
\hline Major menaquinone & MK-7 & MK-7 & MK-7 & MK-7 & MK-7 & MK-7 & MK-7 & MK-7 & MK-7 & MK-7 & $\mathrm{ND}$ \\
\hline DNA G $+\mathrm{C}$ content $(\mathrm{mol} \%)$ & 40.4 & 47.2 & 48.9 & 45.8 & 44.3 & 49.8 & $43-46$ & $46-47$ & $46-47$ & 40.7 & $42-46$ \\
\hline
\end{tabular}


Table 2. Fatty acid profiles of strain Gsoil $664^{\top}$ and related taxa

Strains: 1, Gsoil $664^{\mathrm{T}} ; 2$, T. lutea $\mathrm{DY}^{\mathrm{T}} ; 3$, T. ferrruginea ATCC $13524^{\mathrm{T}} ; 4$, N. koreensis GR20-10 ${ }^{\mathrm{T}} ; 5$, N. yeongjuensis GR20-13 ${ }^{\mathrm{T}}$; 6, C. japonensis IFO $16041^{\mathrm{T}} ; 7$, C. arvensicola IAM $12650^{\mathrm{T}} ; 8$, C. sancti IFO $15057^{\mathrm{T}} ; 9$, C. filiformis IFO $15056^{\mathrm{T}} ; 10$, C. skermanii CC-SG1B ${ }^{\mathrm{T}} ; 11$, C. pinensis UQM $2034^{\mathrm{T}}$. Data for taxa 2-3, 4-5 and 6-11 are from Xie \& Yokota (2006), Weon et al. (2006) and Kämpfer et al. (2006), respectively. Fatty acids that account for $<1.0 \%$ of the total are not shown. Major fatty acids are shown in bold type.

\begin{tabular}{|c|c|c|c|c|c|c|c|c|c|c|c|}
\hline Fatty acid & 1 & 2 & 3 & 4 & 5 & 6 & 7 & 8 & 9 & 10 & 11 \\
\hline \multicolumn{12}{|l|}{ Saturated: } \\
\hline $\mathrm{C}_{14: 0}$ & 1.0 & & & & & & 1.4 & & & 1.8 & \\
\hline$C_{16: 0}$ & 8.5 & 1.1 & 1.7 & 2.6 & 2.9 & 3.0 & 5.1 & 4.2 & 4.3 & 3.5 & 4.2 \\
\hline $\mathrm{C}_{18: 0}$ & 1.9 & & & & & & & & & & \\
\hline \multicolumn{12}{|l|}{ Unsaturated: } \\
\hline $\mathrm{C}_{16: 1} \omega 11 c$ & & & & & & 1.0 & & & & & 1.9 \\
\hline \multicolumn{12}{|l|}{ Branched-chain: } \\
\hline iso- $\mathrm{C}_{13: 0} 3-\mathrm{OH}$ & 1.6 & & & & & & & & & & \\
\hline iso- $\mathrm{C}_{14: 0}$ & & 4.3 & 1.1 & & & & & & & & \\
\hline iso- $\mathrm{C}_{15: 0}$ & 23.4 & 34.8 & 28.4 & 26.8 & 30.6 & 40.0 & 35.3 & 44.0 & 37.3 & 47.3 & 30.4 \\
\hline iso- $\mathrm{C}_{15: 0} 3-\mathrm{OH}$ & & 2.3 & 2.2 & 1.3 & 1.9 & 2.4 & 3.0 & 3.4 & 3.3 & 2.6 & 3.1 \\
\hline iso- $\mathrm{C}_{17: 1} \omega 9 c$ & & & & & & & & 1.1 & & & \\
\hline anteiso- $\mathrm{C}_{15: 0}$ & 3.5 & & & 4.9 & 3.3 & & & & & & \\
\hline \multicolumn{12}{|l|}{ Hydroxy: } \\
\hline $\mathrm{C}_{16: 0} 2-\mathrm{OH}$ & & & & & & 3.0 & & & 1.1 & & \\
\hline $\mathrm{C}_{16: 0} 3-\mathrm{OH}$ & & 3.3 & 2.5 & 1.3 & 2.3 & & 1.7 & & 1.2 & 1.6 & 1.2 \\
\hline $\mathrm{C}_{17: 0} 2-\mathrm{OH}$ & & & & 3.5 & 2.6 & & & & & & \\
\hline $\mathrm{C}_{17: 0} 3-\mathrm{OH}$ & & & & 1.2 & & & & & & & \\
\hline \multicolumn{12}{|l|}{ Unknown:* } \\
\hline ECL 13.565 & 2.1 & 3.2 & 1.3 & & & 3.1 & 3.6 & 3.2 & 2.5 & 4.4 & 2.6 \\
\hline ECL 16.582 & & 1.8 & 1.3 & 1.4 & 1.6 & 1.1 & & 1.3 & 0.9 & & 1.1 \\
\hline \multicolumn{12}{|l|}{ Summed features: } \\
\hline
\end{tabular}

${ }^{\star}$ Unknown fatty acids have no name listed in the peak library file of the MIDI system and therefore cannot be identified; equivalent chain-lengths are given. Summed feature 3 comprises any combination of iso- $\mathrm{C}_{15: 0} 2-\mathrm{OH}$ and/or $\mathrm{C}_{16: 1} \omega 7 c$ and summed feature 4 comprises any combination of iso- $\mathrm{C}_{17: 1} \mathrm{I}$ and/or anteiso- $\mathrm{C}_{17: 1} \mathrm{~B}$.

\section{Description of Segetibacter koreensis sp. nov.}

Segetibacter koreensis (ko.re.en'sis. N.L. masc. adj. koreensis of Korea, from where the novel organism was isolated).

Possesses the following properties in addition to those given in the genus description. Cells are 1.0-1.3 $\times 1.6-$ $2.0 \mu \mathrm{m}$ in size. Colonies on $\mathrm{R} 2 \mathrm{~A}$ agar plates at $30^{\circ} \mathrm{C}$ are circular, convex, non-luminescent and yellow. On R2A agar medium, the strain is able to grow at $15-30{ }^{\circ} \mathrm{C}$, but not at 4 or $37{ }^{\circ} \mathrm{C}$. Growth occurs at pH 5.5-8.5 and at $\mathrm{NaCl}$ concentrations of up to $3 \%$; growth is optimal at pH 7.0 in the absence of $\mathrm{NaCl}$. N-acetyl-D-glucosamine, Lfucose, glucose, histidine, maltose, mannose, D-melibiose, L-proline, rhamnose and salicin are assimilated. Positive for the hydrolysis of aesculin, urea and arginine dihydrolase. Negative reactions are observed for $\beta$-galactosidase activity, indole production, glucose fermentation and the assimilation of acetate, adipate, L-alanine, L-arabinose, caprate, citrate, gluconate, glycogen, 3-hydroxybenzoate, 4-hydroxybenzoate, 3-hydroxybutyrate, inositol, itaconate, 2-ketogluconate, 5ketogluconate, lactate, malate, malonate, mannitol, phenylacetate, propionate, D-ribose, L-serine, D-sorbitol, suberate, sucrose and valerate. According to the API ZYM gallery, gives a positive reaction in tests for $N$-acetyl- $\beta$-glucosaminidase, acid phosphatase, alkaline phosphatase, $\alpha$-galactosidase and leucine arylamidase; weakly positive for $\alpha$-glucosidase, $\beta$ glucosidase and $\alpha$-fucosidase and negative for chymotrypsin, cystine arylamidase, esterase (C4), esterase lipase (C8), 


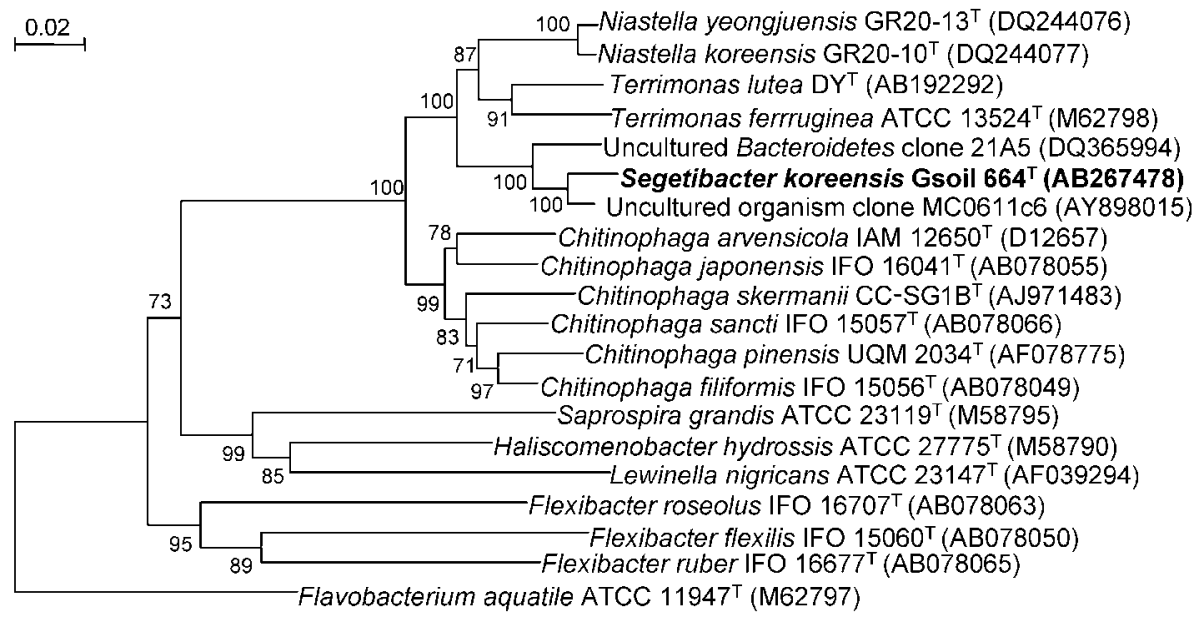

Fig. 1. Rooted phylogenetic tree based on $16 \mathrm{~S}$ rRNA gene sequences of strain Gsoil $664^{\top}$ and related bacteria in the phylum Bacteroidetes. This tree was constructed using the neighbour-joining method (Saitou \& Nei, 1987) with a two-parameter distance matrix Kimura (1983) and pairwise deletion. Bootstrap percentages (of 1000 replications) greater than $70 \%$ are shown at the branch points. Bar, 20 nucleotide substitutions per 1000 nucleotides.

$\beta$-galactosidase, $\beta$-glucuronidase, lipase (C14), $\alpha$-mannosidase, naphthol-AS-BI-phosphohydrolase, trypsin and valine arylamidase. The DNA G $+\mathrm{C}$ content is $40.4 \mathrm{~mol} \%$.

The type strain, Gsoil $664^{\mathrm{T}}\left(=\right.$ KCTC $12655^{\mathrm{T}}=\mathrm{DSM}$ $\left.18137^{\mathrm{T}}\right)$, was isolated from the soil of a ginseng field in Pocheon Province, South Korea.

\section{Acknowledgements}

This work was supported by the 21C Frontier Microbial Genomics and Application Center Program (grant MG05-0101-4-0) of the Ministry of Science and Technology, Republic of Korea.

\section{References}

Atlas, R. M. (1993). Handbook of Microbiological Media. Edited by L. C. Parks. Boca Raton, FL: CRC Press.

Bowman, J. P., McCammon, S. A., Brown, M. V., Nichols, D. S. \& McMeekin, T. A. (1997). Diversity and association of psychrophilic bacteria in Antarctic sea ice. Appl Environ Microbiol 63, 3068-3078.

Buck, J. D. (1982). Nonstaining (KOH) method for determination of Gram reactions of marine bacteria. Appl Environ Microbiol 44, 992-993.

Buczolits, S., Denner, E. B. M., Vybiral, D., Wieser, M., Kämpfer, P. \& Busse, H.-J. (2002). Classification of three airborne bacteria and proposal of Hymenobacter aerophilus sp. nov. Int J Syst Evol Microbiol $52,445-456$.

Felsenstein, J. (1985). Confidence limits on phylogenies: an approach using the bootstrap. Evolution 39, 783-791.

Garrity, G. M. \& Holt, J. G. (2001). The road map to the Manual. In Bergey's Manual of Systematic Bacteriology, 2nd edn, vol. 1, pp. 119-166. Edited by D. R. Boone, R. W. Castenholz \& G. M. Garrity. New York: Springer.
Hall, T. A. (1999). BioEdit: a user-friendly biological sequence alignment editor and analysis program for Windows 95/98/NT. Nucleic Acids Symp Ser 41, 95-98.

Hiraishi, A., Ueda, Y., Ishihara, J. \& Mori, T. (1996). Comparative lipoquinone analysis of influent sewage and activated sludge by highperformance liquid chromatography and photodiode array detection. J Gen Appl Microbiol 42, 457-469.

Im, W.-T., Jung, H.-M., Cui, Y.-S., Liu, Q.-M., Zhang, S.-L. \& Lee, S.-T. (2005). Cultivation of the three hundreds of bacterial species from soil of a ginseng field and mining the novel lineage bacteria. In Proceedings of the International Meeting of the Federation of Korean Microbiological Societies, abstract A035, p. 169. Seoul: Federation of Korean Microbiological Societies.

Kämpfer, P., Young, C. C., Sridhar, K. R., Arun, A. B., Lai, W. A., Shen, F. T. \& Rekha, P. D. (2006). Transfer of [Flexibacter] sancti, [Flexibacter] filiformis, [Flexibacter] japonensis and [Cytophaga] arvensicola to the genus Chitinophaga and description of Chitinophaga skermanii sp. nov. Int J Syst Evol Microbiol 56, 2223-2228.

Kim, M. K., Im, W.-T., Ohta, H., Lee, M. \& Lee, S.-T. (2005). Sphingopyxis granuli sp. nov., a $\beta$-glucosidase producing bacterium in the family Sphingomonadaceae in $\alpha-4$ subclass of the Proteobacteria. J Microbiol 43, 152-157.

Kimura, M. (1983). The Neutral Theory of Molecular Evolution. Cambridge: Cambridge University Press.

Kumar, S., Tamura, K. \& Nei, M. (2004). MEGA3: integrated software for molecular evolutionary genetics analysis and sequence alignment. Brief Bioinform 5, 150-163.

Mesbah, M., Premachandran, U. \& Whitman, W. B. (1989). Precise measurement of the $\mathrm{G}+\mathrm{C}$ content of deoxyribonucleic acid by high-performance liquid chromatography. Int J Syst Bacteriol 39, 159-167.

Moore, D. D. \& Dowhan, D. (1995). Preparation and analysis of DNA. In Current Protocols in Molecular Biology, pp. 2-11. Edited by F. M. Ausubel, R. Brent, R. E. Kingston, D. D. Moore, J. G. Seidman, J. A. Smith \& K. Struhl. New York: Wiley. 
Saitou, N. \& Nei, M. (1987). The neighbor-joining method: a new method for reconstructing phylogenetic trees. Mol Biol Evol 4, 406-425.

Sasser, M. (1990). Identification of bacteria by gas chromatography of cellular fatty acids, MIDI Technical Note 101. Newark, DE: MIDI Inc.

Ten, L. N., Im, W.-T., Kim, M.-K., Kang, M.-S. \& Lee, S.-T. (2004). Development of a plate technique for screening of polysaccharidedegrading microorganisms by using a mixture of insoluble chromogenic substrates. J Microbiol Methods 56, 375-382.

Thompson, J. D., Gibson, T. J., Plewniak, F., Jeanmougin, F. \& Higgins, D. G. (1997). The CLUSTAL_X windows interface: flexible strategies for multiple sequence alignment aided by quality analysis tools. Nucleic Acids Res 25, 4876-4882.

Weon, H.-Y., Kim, B.-Y., Yoo, S.-H., Lee, S.-Y., Kwon, S.-W., Go, S.-J. \& Stackebrandt, E. (2006). Niastella koreensis gen. nov., sp. nov. and Niastella yeongjuensis sp. nov., novel members of the phylum Bacteroidetes, isolated from soil cultivated with Korean ginseng. Int J Syst Evol Microbiol 56, 1777-1782.

Xie, C.-H. \& Yokota, A. (2006). Reclassification of [Flavobacterium] ferrugineum as Terrimonas ferruginea gen. nov., comb. nov., and description of Terrimonas lutea sp. nov., isolated from soil. Int J Syst Evol Microbiol 56, 1117-1121. 